Paulina Nicko-Stępień

Pontifical Faculty of Theology, Wrocław

\title{
Louvain Edition of the Vulgate and the New Testament in the Translation by Jakub Wujek from 1593 Study of Matthew 16:13-20
}

Jakub Wujek SJ (1541-1597), a Catholic priest, is considered to be one of the most distinguished Biblical translators of the Counter-Reformation period. He mastered Theology, Philosophy and Biblical Philology well. He understood the power and importance of the printed word published in national languages and the significance of the Scripture reading, as it was the book that constituted a focus of interests not only of the most distinguished minds of the epoch, but also of the people with, at least, basic education.

In recent years, important scientific studies on Jakub Wujek and his translations have been published. The most significant ones include a reprint of the 1599 Wujek's Bible together with an essay published in the Biblia Slavica series. ${ }^{1}$ Among Polish experts on Jakub Wujek, the following researchers should be mentioned: ${ }^{2}$ Danuta

${ }^{1}$ Biblia to iest Ksiegi Starego y Nowego Testamentu wedtug Eacinskiego przektadu starego, $w$ kośćiele powszechnym przyiętego, na Polski ięzyk z nowu z pilnośćia przetożone. Z doktadaniem textu Żydowskiego y Greckiego, y z wyktadem Katholickim, trudnieyszych mieysc, do obrony Wiary świętej i powszechney przeciw kacerztwom tych czasów należacych. Przez D. Jakuba Wuyka z Wagrowca Theologa Societatis Iesu. W Krakowie, Roku Pańskiego M.D.XCIX, ed. I. Kwilecka, H. Rothe (Padeborn, München and Wien, 2010; Biblia Slavica. Polnische Bibeln, V/1-2).

2 The researchers are listed according to the following academic disciplines: the History of the Book, the Biblical studies, the Philology, the Bibliography and Information Science. 
Bieńkowska, ${ }^{3}$ Joanna Sobczykowa, ${ }^{4}$ Maria Kossowska, ${ }^{5}$ Hugolin Langkammer, ${ }^{6}$ Janina Czerniatowicz ${ }^{7}$ and Dariusz Kuźmina. ${ }^{8}$

Until recently, freely chosen Biblical texts (Greek, Latin and Hebrew) were usually used as a basis for comparative analysis in research on Wujek's translation of the Bible and his translation technique. As did M. Kossowska, who completely ignored the Louvain Vulgate - the very basis for the Wujek's translation. By omitting one of the most important texts used in Wujek's translation practice, she presented rather imprecisely the method of his work, as she assumed that Wujek himself collated different versions, while making textual criticism. ${ }^{9}$ So did D. Bieńkowska. ${ }^{10}$ So it was usually ignored that the sixteenth-century and modern Latin and Greek texts of the Bible are not identical and that the sixteenth-century Biblical texts in Latin (the Vulgate), Greek (the Septuagint) and Hebrew vary depending on the edition. Naturally, it is not about differences that change the Articles of Faith but minute variants reflected in the translation (eg. a change in a word order, a presence or absence of a word or, less frequently, a verse etc.). Even the modern editions of the Vulgate or the Greek New Testament were used in the research on Wujek's translation. ${ }^{11}$

${ }^{3}$ D. Bieńkowska, “Jak Jakub Wujek Pismo Święte na język polski przekładał (O warsztacie tłumacza i technice przez niego stosowanej)," Bobolanum 9 (1998), pp. 27-52; eadem, "Rola glos marginalnych w przekładzie Biblii J. Wujka," Acta Universitatis Lodziensis. Folia Linguistica 23 (1990), pp. 21-29; eadem, Styl językowy przektadu Nowego Testamentu Jakuba Wujka (na materiale czterech Ewangelii) (Łódź, 1992).

4 J. Sobczykowa, Myśl o języku w komentarzu biblijnym ks. Jakuba Wujka (Katowice, 2001).

${ }^{5}$ M. Kossowska, Biblia w jezzyku polskim, vol. 1 (Poznań, 1968), pp. 313-360.

${ }^{6}$ H. Langkammer, "Przekład Biblii Wujka na tle zmagań i potrzeb religijno-teologicznych ówczesnego Kościoła w Polsce,” Bobolanum 9 (1998), pp. 53-63.

7 J. Czerniatowicz, Niektóre problemy naukowe grecystyki w pracach biblistów polskich XVI i XVII wieku. Teksty greckie a polskie przektady (Wrocław, 1969; Monografie w Dziejów Nauki i Techniki, vol. 53), pp. 70-84.

${ }^{8}$ D. Kuźmina, Jakub Wujek (1541-1597). Pisarz, ttumacz i misjonarz (Warszawa, 2004).

${ }^{9}$ Kossowska, Biblia, pp. 322-326. The author presumed that Wujek himself wrote the marginal notes.

${ }^{10}$ Bieńkowska, "Rola glos," p. 22. The author writes that some of the marginal notes are linked to Wujek's referring to various Greek and Latin texts of the Holy Scripture. She probably assumed that the translator himself made the notes on textual criticism.

${ }^{11}$ Eadem, "Jak Jakub Wujek," p. 39. The author clearly emphasises that she refers to the 1975 Vulgate edition. Cf. L. Moszyński, "Stworzenie świata (Gn 1,1-31) 
In the bibliography of her publications, J. Sobczykowa listed only the twentieth-century editions of the Vulgate and Septuagint, as did both D. Bieńkowska and M. Kossowska. ${ }^{12}$ The most thorough research was carried out by J. Czerniatowicz, as she used the sixteenth-century editions of the Bible, nevertheless from the 1690s so not the ones that Wujek based his work on. ${ }^{13}$ The translator clearly stated, which edition was used: "The Latin issue that I followed which is by the Louvain theologians thoroughly perused, revised and corrected and compared with the original Greek and Assyrian and old Latin handwritten books, that Plantinus in Antorf [Antwerp] printed in Anno Domini $1574 " .{ }^{14}$

There are many more similar examples of using contemporary Biblical texts to research Wujek's translation. ${ }^{15}$ But isn't such a method of research a methodological error? Can one obtain slightly different results by employing the same genuine sixteenth-century editions used by Wujek to compare his translation? Would referring to the original editions change our perception of the technique and method of work of the Biblical scholar from Wagrowiec? The aim of this paper is to present the results of the research on the pericope Mt. 16:1320 on the basis of Bible editions known to Wujek.

Jakub Wujek and his technique

Starting the translation work, Wujek decided to base it mainly on a text called editionem vulgatam. He respected its authority approved by the Catholic Church, mostly at the Council of Trent (1545-1563),

w przekładzie Wujka z Wulgaty (1599) i Budnego z hebrajskiego (1572),” in: Jan Jakub Wujek. Ttumacz Biblii na język polski. W czterechsetna rocznice wydania Nowego Testamentu 1593-1993. Księga referatów wygtoszonych na konferencji 26 kwietnia 1993 (Łódź, 1994), pp. 50-58. The author also refers to the 1975 Stuttgart edition of Vulgate.

12 From 1983 and 1979. See Sobczykowa, Myśl o języku, s. 247. D. Bieńkowska repeatedly referred to the 1980 s Vulgate, whereas M. Kossowska to the Clementine Vulgate (the 1956 Roman edition)

${ }^{13}$ Czerniatowicz, Niektóre problemy, p. 127.

${ }^{14}$ J. Wujek, "Przedmowa do czytelnika," in: Nowy Testament $w$ przektadzie ks. $d r$ Jakuba Wuika T.J. z roku 1593, ed. W. Smereka (Kraków, 1966), p. LXVIII.

${ }^{15}$ P. ex. E. Siatkowska, "Samodzielność przekładu Nowego Testamentu przez Jakuba Wujka, Jana Blahoslava i Michała Frencla," in: Biblia a kultura Europy. 2000 lat chrześcijaństwa, vol. 1, ed. M. Kamińska, E. Małek (Łódź, 1992), pp. 73-80; D. Bieńkowska, "Jakub Wujek - nowator czy tradycjonalista?," in: ibidem, pp. 143-146; E. Bereza, "Odmiana nazw własnych w Nowym Testamencie Biblii Wujka i Biblii Tysiąclecia,” in: ibidem, p. 153. 
which - as Wujek wrote - "praises the Latin text and orders it to be considered reliable". ${ }^{16}$ The next reason for choosing St. Jerome's version was, in Wujek's opinion, the smaller distortion of the Latin text than of the Greek one. As we read in The Preface, the Latin Church had only one homoousian sect and as they lacked the great minds, so, naturally, they caused no serious harm by their translations. ${ }^{17}$ Wujek used the Louvain edition, printed in 1574 in Antwerp. As a theologian and exegete, he did not contented himself with St. Jerome's text, but also referred to the Greek original and, in the case of the Old Testament, to the Hebrew one, to give the reader the possibility to dispute with the heterodox versions and thereby to limit the misinterpretation.

Translating the Bible, Wujek was careful not to make mistakes that distort the original meaning of the Holy Scripture. In his work, Wujek, as a heir to the noblest tradition in arte translatoria obliged by the Church to stay faithful to the Vulgate, followed St. Jerome's three rules: to understand the meaning, to understand the text and to retain its elegance and artistic values. Furthermore, he tried to convey old expressions and ancient religious terminology by deliberately not creating neologisms and terms unknown to the Christians. Basing on the conviction that the literality of the translation not necessarily contributes to its clarity, Wujek made a golden rule out of all the aforementioned rules: to stay faithful to the Vulgate (and to some extent to the original versions), when it comes to the language, but, at the same time, to care about the clarity of the Polish text. ${ }^{18}$ What made his translations to stand out is the vast amount of linguistic appendices in italics and expanding the text. They also allowed to convey the meaning more accurately, depending on context and to understand a word. The introduced phrases and expressions without equivalents in original languages were supposed to strengthen both the integrity and dynamics of the text.

16 Wujek, "Przedmowa," p. LVII.

17 See ibidem, p. LIX.

18 S. Sawicki, "Biblia Wujka w kulturze polskiej," Studia Gnieźnieńskie 1 (1975), pp. 315-320. 
Editions that constitute the basis of the 1593 New Testament translation ${ }^{19}$ Wujek based his New Testament translation on the two Bible editions: the Louvain Vulgate ${ }^{20}$ and the Antwerp Polyglot. The Vulgate is a Latin translation of the Bible from Greek, Hebrew and Aramaic made by St. Jerome (ca. 345-420). A lot of different editions of the text were published during the Renaissance, including the Louvain Vulgate. The work on it begun in 1546 under Hentenius (1499-1566) after the comparison of the best printed editions of the Bible and the thirty manuscripts. In the following year the translation of the Holy Scripture entitled Biblia sacra ad vetustissima exemplaria castigate was printed by Barthélemy de Grave in Louvain. The work was then continued, this time using seventy manuscripts and it resulted in the 1565 and 1569 editions of Louvain Vulgate printed in Antwep by Christophe Plantin, followed by their reprints i.a. by Lucantonio Giunto (1457-1538) in Venice in 1571 and 1572. Two years later, Benito Arias Montano (1527-1598) the editor of the so-called Antwerp Polyglot version - once more revised the former editions and published a new Vulgate, also printed by Plantin in 1574. This version acquired the textus receptus status within the Catholic Church, which it enjoyed until the Sistine Vulgate was published (1590). ${ }^{21}$ That very 1574 edition was used by Jakub Wujek.

The Antwerp Polyglot (1572) ${ }^{22}$ was a multilingual Bible edition with an emphasis on the Latin, Greek sources and Syriac Peshitta

${ }^{19}$ Nowy Testament Pana naszego IESVSA CHRISTVSA. Z nowu z Laćińskiego y z Gręckiego na Polskie wiernie a szczyrze przetożony: y Argumentami abo Summariuszami każdych Kśiag / y Rozdźiatow / y Annotacyami po brzegach obiaśniony. Przydane sa Nauki y Przestrogi mato nie za kazdym Rozdźiatem: Porownanie Ewangelistow SS. Dźieie y drogi rozmaite Piotra y Pawta S. y Regestr rzeczy gtownieyszych na końcu. Przez D. IAKVBA WVYKA, Theologa Societatis IESV. Z dozwoleniem Starszych. Pod rozsądek Kośćiota S. Powszechnego Rzymskiego wszytko niech podlęże (Kraków, 1593; copy Wrocław, Ossoliński Library [Biblioteka Zakładu Narodowego im. Ossolińskich], sign. XVI.Qu.3065).

${ }^{20}$ Biblia sacra: Quid in hac ediotione a Theologis Louaniensibus praesitum sit, paolopost indicatur (Antverpiae: K. Plantinus, 1574; 8 ; copy Wrocław, Chapter Library [Biblioteka Kapitulna], I 24.O).

${ }^{21}$ R. Pietkiewicz, W poszukiwaniu "szczyrego" Stowa Bożego. Recepcja zachodnioeuropejskiej hebraistyki w studiach chrześcijańskich w Rzeczypospolitej dobry renesansu (Wrocław 2011; Rozprawy naukowe PWT, vol. 86), pp. 89-90. Cf. also G. Voste, "La volgata al Concilio di Trento," Biblica 27 (1946), pp. 301-319.

22 Biblia Sacra Hebraice, Chaldaice, Graece et Latine. Philippi II Reg. Cathol. Pietate Et Studio Ad Sacrosanctae Ecclesiae Usum, vol. 1-8 (Antverpiae, 1569-1572; copy Wrocław, University Library (Biblioteka Uniwersytecka), sign. 464835). 
(for the New Testament). Such a collation of the original text with a translation was to contribute, mainly, to the textual criticism. The Polyglot was printed in Antwerp in 1572 by Plantin under Benito Arias Montano, on the commission of Philip II, the King of Spain, hence the other title: Biblia Regia or Plantiniana. ${ }^{23}$

Comparative study of different versions of $\mathrm{Mt}$. 16:13-20

To establish Wujek's method of translation work, we shall compare his translation and the texts that constituted its basis. For this purpose, we will use a fragment from Mt. 16:13-20 (the promise of Primacy) and collate the 1593 Wujek version (later: WNT), the Louvain Vulgate (later: LV) and the Syriac (AnPS), Latin (AnPV) and Greek (AnPG) versions from the Antwerp Polyglot.

Verse 13:

1593 WNT: fA gdy przyszedł Jezus w strony Cezarejej Filipowej, pytał uczniów swoich mówiąc: $g$ Czym * mienią być ludzie Syna Człowieczego?

* mnie z L. K. G. S. ale Hieronim tego słówka nie czytał ${ }^{24}$. $f$ Mk. 8:2725

g Lk. 9:18

LV: $\quad \quad$ Venit autem Iesus in partes Caesareae Philippi: \& interrogabat discipulos suos, dicens, || Quem * dicunt homines esse filium hominis?

Mk 8:27

Lk 9:18

*me 3.

MS. R. G. S. at Hier.

AnPS: Quum autem venisset Jeschua in regionem Caesareae Philippi, interrogavit discipulos suos, inquiens, Quid dicunt de me homines, me esse filium hominis?

23 See "Biblia Polyglotta," in: Encyklopedia wiedzy o ksiązce, ed. A. Birkenmajer, B. Kocowski, J. Trzynadlowski (Wrocław, 1971), pp. 146-148.

${ }^{24}$ An asterisk $\left(^{*}\right)$ signalizes that Wujek omitted the following word, although it appears in the texts below. Cf. Wujek, "Przedmowa," pp. LXVIII-LXIX. Letter designations and acronymes have been explained in the index of abbreviations.

${ }^{25}$ A lower case letter indicates references to parallel places in the Bible. 
AnPV: $\quad$ Venit autem Iesus in partes Caesareae Philippi: \& interrogabat discipulos suos, dicens, Quem me dicunt homines esse, filium hominis?

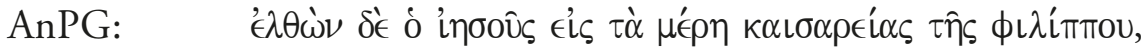

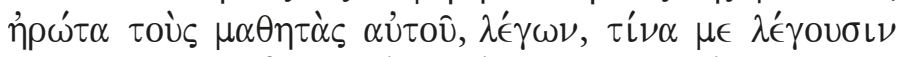

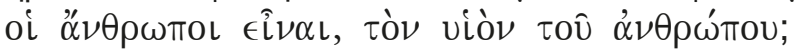

Mk. 8:27

Lk. 9:18

The comparative analysis of the verse shows that Wujek used LV, which is indicated, among others, by the same references to the parallel passages and critical textual remarks. But he did not slavishly follow the Latin version, adding absent words eg. "gdy" or omitting eg. conjunction " $i$ ". He also consulted AnP, as he evidently derived from its texts, eg. translating the imperfect interrogabat as the Polish imperfect aspect "pytał". Nevertheless, Wujek tried to convey the meaning of Jesus' question by means of a Polish construction that would be the closest to the Latin syntax ACI. It appears in a similar form in other Polish versions of the Bible. In the translation of the question he followed LV, which omits the pronoun "me", and replaced the pronoun with the same reference as LV. In the marginal notes Wujek mentions the Latin, Greek and Syriac manuscripts, as does LV.

Verse 14:

1593 WNT: A oni rzekli: Jedni Janem Krzcicielem, a drudzy Eliaszem, inszy też Jeremiaszem, abo jednym z proroków.

A oni rzekli.) Gdy P. Chrystus pytał uczniów swoich o ludzkim o sobie mniemaniu, tedy mu wszyścy Apostołowie odpowiedzieli. Ale gdy ich zapytał, coby też sami o nim rozumieli, tedy Piotr, jako książę i głowa wszytkich Apostołów, sam za wszytkie odpowiedział. [Chrysostomus Homil: 55. in Matthaeum].

LV: $\quad$ At illi dixerunt: Alij Iohannem Baptistam, alij autem Eliam, alij vero Ieremiam, aut unum ex prophetis.

AnPS: $\quad$ Ipsi vero dixerunt, Sunt qui dicunt Jouchanon Baptistam, alij vero Jlijo, alij denique Ermio aut unum ex prophetis. 
AnPV: $\quad$ At illi dixerunt, Alij Iohannem Baptistam, alij autem Eliam, alij vero Ieremiam, aut unum ex prophetis.

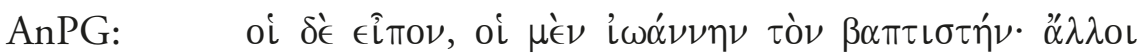

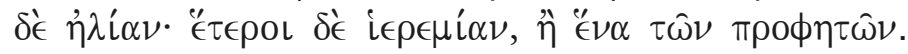

All the Latin versions have an identical text. Wujek seems to have derived the idea of counting-out from AnPG, as, similarly, he uses different expressions: "jedni [- $[$, a drudzy $[--]$, inszy też [- $[-$ ", and does not follow here either LV or AnPV, which both use the word "alij". Wujek, like LV, did not place any reference to the verse 14 . Instead, he wrote a commentary based on Patristic sources, which is a testimony of his creativity. He used other translations, but only as an aid, and made his own interpretation of the text.

Werset 15 :

1593 WNT: Rzekł im - Jezus: A wy kim mię być powiedacie? 15. G. $^{26}$

LV: $\quad$ Dicit illis Iesus: Vos autem quem me esse dicitis? se non legisse, apte loquitur

AnPS: $\quad$ Dixit eis, Vos autem quem me dicitis esse?

AnPV: $\quad$ Dicit illis Iesus, Vos autem quem me esse dicitis?

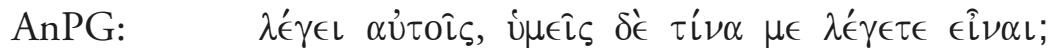

There is no difference between the Latin versions, too. Wujek translates the verse literally. He marks with an arrow the word that AnPG lacks, but which is present in the Latin text i.e. Jesus. Similarly to the verse 13 , Wujek conveyed the Latin $A C I$ syntax by an infinitive: "kim mię być powiedacie?" But the use of the past form he drew, most probably, from AnPS, which has dixit instead of dicit or $\lambda^{\prime} \epsilon \in \mathrm{l}$, as have the remaining texts.

${ }^{26}$ An arrow $(\bullet)$ means that the following word does not appear in the respective manuscripts, but Wujek includes it (in this way he follows LV); a number indicates a number of the texts. 
Verse 16:

WNT 1593: A Simon Piotr odpowiedając rzekł: ${ }^{b}$ Tyś jest Chrystus Syn Boga żywego

${ }^{b}$ Jn. 6:69

Tyś jest Chrystus.) Piotr napirwszy z Boskiego objawienia poznał dwie najwyższe tajemnice wiary naszej: rozdzielność person w Bóstwie i wcielenie Syna Bożego. Hilarius na to miejsce i Athanasius sermone 4. contra Arianos, Chrysostomus, Cyrillus, Augustinus i Leo. Abowiem przystało, aby ten który miał być głową i fundamentem kościoła Chrystusowego [inner: Mt. 16:18 i 19], i którego wiarę miał nieomylną uczynić [inner: Lk. 22:32], przodek też otrzymał w tym wyznaniu, które tak dalece przechodziło wszytko przyrodzenie i wszytek rozum ludzki (zwłaszcza patrząc na człowieczeństwo i na ułomność ciała P. Chrystusowego), iż dla tej wiary i jawnego jej wyznania, nazwany jest Piotr błogosławionym, jako i Abraham dla swej wiary, i otrzymał jako i on, wielbić wielkie, a znamienite obietnice, tak sobie, jako i potomkom swoim [inner: Rz 4:3]. Przetoż ś[w]. Bazyli mówi, iż Piotr, dla zacności wiary, zbudowanie Kościoła na sobie otrzymał [inner: Basilius libro 2. Contra Euno].

LV: $\quad$ Respondens Simon Petrus dixit, \| Tu es Christus filius Dei vivi.

Jn 6:69.

AnPS: $\quad$ Respondit Schemeoun Kipho, \& ait, Tu es Meschicho filius Dei vivi.

AnPV: $\quad$ Respondens autem Simon Petrus, dixit, Tu es Christus filius Dei vivi.

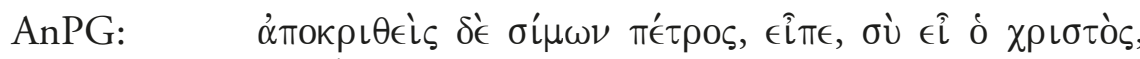

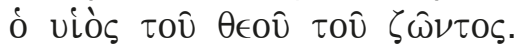

Jn 6:69

Wujek departs from the Latin syntax by changing the subject's place. $A$ may be the equivalent of the Latin autem and the Greek $\delta \epsilon$, 
which are in both AnPV and AnPG. The comparison of texts shows that Wujek still used LV and AnP, because he placed in a margin a reference to Jn. 6:69. Moreover, in the commentary, he used numerous references to the Church Fathers and Doctors, on whose works he drew, describing not just Peter's confession, but lecturing on dogmatic truths, such as the autonomy of the Divine Persons or Incarnation of the Son of God and emphasising Peter's Primacy and infallibility. These elements of the commentary are of the distinct polemical nature against the Reformation camp, especially the Antitrinitarians.

Verse 17:

1593 WNT: A odpowiedając Jezus rzekł mu: Błogosławionyś jest Simonie ${ }^{i}$ Barjona, bo "ciało i kreẃ nie objawiła tobie, ale Ociec mój, który jest w niebiesiech.

${ }^{i}$ Bariona znaczy synu Jony

"Ciało i krew, miasto człowieka. Hebraizm.

${ }^{i}$ Jn. $1: 42$

Btogostawionyś jest Simonie synu Jony.) Theophilaktus tak na to miejsce pisze: „Oddarował Pan Piotrowi dawszy mu tę wielką zapłatę, iż na nim Kościół swój zbudował”. A Chryzostom tak wykłada te słowa [Hom: 55 in Matth]: „Jakoś ty jest własnym synem Jonaszowym, takem ja jest synem ojca mego, tejże istności z nim. [outer: CHRYSTUS RODZONY SYN BOŻY] Bo gdyby był Piotr nie wierzył, że Chrystus jest Synem Bożym przyrodzonym, urodzonym z Ojca, ale tylko Synem uczynionym abo sposobionym, nie trzebaćby mu było na to objawienia $\mathrm{z}$ nieba, aniby był zasłużył tak wielkiego błogosławieństwa”.

LV: Respondens autem Iesus, dixit ei: Beatus es Simon \| Bar-Iona: quia caro \& sanguis non revelavit tibi, sed pater meus, qui in caelis est.

Jn. 1:42

AnPS: $\quad$ Respondit Jeschua, \& dicit ei, Beatus es, Schemeoun Bere de-Javno [fili columbae,] siquidem caro $\&$ sanguis non revelavit tibi, sed pater meus qui in caelis est. 
AnPV: $\quad$ Respondens autem Iesus, dixit ei, Beatus es Simon BarIona: quia caro \& sanguis non revelavit tibi, sed pater meus qui in caelis est.

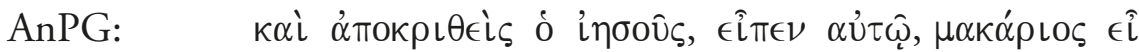

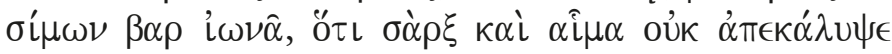

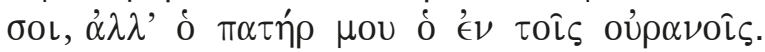

Jn. 1:42

Wujek again gives the same reference as LV - to Jn. 1:42. In the margin, he explains the word "Barjona", providing it with a Patristic commentary and translates a Hebraism "ciało i krew" (body and blood).

Verse 18:

1593 WNT: A ja też tobie powiedam, iżeś ty jest "opoka, a na tejże opoce zbuduję Kościół mój, a brany piekielne nie zwyciężą " go.

Piotr. Petros po grecku; Cepha po żydowsku; skała abo opoka po polsku ${ }^{27}$.

" Abo jej, to jest opoki.

Tyś jest Opoka.) Z greckiego tak się właśnie ma przełożyć: Tyś jest opoka, abo skała, a na tej opoce, abo skale zbuduję mój Kościół. Przetoż się tu jawnemi fałszerzemi Pisma Świętego pokazali Czechowic i Budny, tłumacze Nowego Testamentu, Nowokrzczeńcy, gdy tak przełożył jeden: „Tyś jest opoczysty”; a drugi: „Tyś jest skalny”. Bo w greckim nie jest $\pi \in \tau \rho \alpha$ los ani

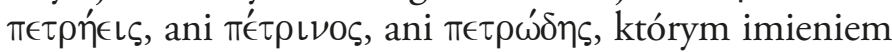
zowie Mateusz [inner: Mt 13,5] i Marek ś[w.] [inner: Mk. 4:5] ziemie opoczystą, na której nasienie wszczedszy wnet usycha, ale $\pi \epsilon ́ \tau \rho o \varsigma$, co zgoła toż jest co i $\pi \dot{\epsilon} \tau \rho \alpha$ po naszemu kamień, opoka, abo skała; po syryjsku, chaldejsku i po żydowsku Cepha [inner: Jn. 1:42]. A gdyż to jest pewna, że Pan Chrystus do Piotra nie po łacinie, ani po grecku, ale językiem zwyczajnym,

27 This symbol (") precedes an explanation of more difficult passages. 
po syryjsku mówił: Tyś jest Cepha, a na tej Cephie zbuduję mój Kościół. Tedyć i to rzecz nad słońce jaśniejsza, że Pan tymi słowy nie na kim inszym jedno na Pietrze obiecał Kościół swój zbudować, uczyniwszy go pirwszym po sobie fundamentem, to jest głową Kościoła swojego. Bo co jest fundament w budowaniu, to jest głowa w ciele, król w królestwie, a gospodarz w domu. A przetoż zbór walny chalcedoński, na którym było 630. Ojców greckich i łacińskich, zowie Piotra opoką i fundamentem kościoła powszechnego [Acti 3]. I przed dwanaście set lat, jako Augustyn ś[w.] świadczy, toż śpiewano jawnie w kościele, w onych wierszach ś[w.] Ambrożego [In ps: cot. par. don.] [outer: HOC IPSA ECCLESIAE CANETE CULPAM DILUIT]. Prze co Hieronim ś[w.] i Augustyn ś[w.] namiastki Piotra ś[w]. i stolicę jego zową tą opoką, na której Pan Chrystus Kościół swój zbudował [Hiero: Ad Damasum]; iż Piotr jest opoka, nie jako prosty człowiek, abo szczególna osoba, ale jako biskup najwyższy po Chrystusie. Bo P. Chrystus, jako ś[w.] Basilius powiada, tytułów i zacności swoich rad użycza drugim [Basi: hom: de poenit.]. Kapłanem jest i kapłany czyni. Opoką jest i opoką czyni; a rzeczy swe własne daje sługom swoim. Ale jeśli przeciwnicy wszystkim doktorom chrześcijańskim wiary nie dawają, niech na koniec samym Żydom wierzą. Niech słuchają co Elias, rabin żydowski, pisze tymi słowy: „Cepha po chaldejsku znaczy skałe i mocność. Którym imieniem nazwał Jezus Nazareński ucznia swego, dając znać, iż on miał być głową i twierdzeniem wiary jego" [Elias in Thisbi].

A brany piekielne.) Stałość i trwałość wieczna tu jest obiecana, nie jedno kościołowi, ale i opoce na której Kościół jest zbudowany. Jako przypomina Orygenes sławny na tym miejscu. A tak osobnym przywilejem Piotrowi obiecano, że stolica jego nigdy nie upadnie. Jako i Augustyn ś[w.] wyznawa tymi słowy: „Liczcie biskupy, od samego Piotra na stolicy jego, a patrzajcie w onym rzędzie, który za kim idzie. Ten ci jest tą 
opoką, której nie zwyciężą brany piekielne. Której obietnice iż nie mieli inni Apostołowie, przetoż nie dziw, że ich stolice branam piekielnym ustąpić musiały" [August: In psa: cont. par. don.].

LV: $\quad$ Et ego dico tibi, quia tu es Petrus: \& super hanc petram aedificabo ecclesiam meam, $\&$ portae inferi non praevalebunt adversus eam.

AnPS: Quinetiam ego dico tibi,Tu es Kipho [petra,] \& super hanc petram aedificabo Ecclesiam meam, \& porte inferorum non praevalebunt ei.

AnPV: $\quad$ Et ego dico tibi, Quia tu es Petrus: \& super hanc petram aedificabo ecclesiam meam, \& porte inferi non praevalebunt adversus eam.

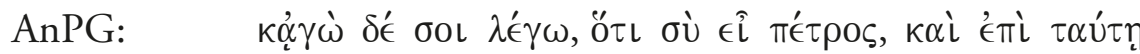

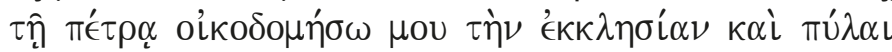

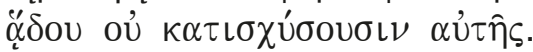

This is the most disputed verse of the whole pericope, where you can see Wujek's intense dispute with Szymon Budny and Marcin Czechowic, who - in Wujek's opinion - mistranslated Peter's name. Wujek translates the Greek word $\pi \dot{\epsilon} \tau \rho \circ \varsigma$ as a noun opoka (adding "Piotr" in a margin) and not as an adjective "opoczysty" or "skalny" (as Czechowic and Budny did). He substantiates his choice by quoting Patristic writings and the original text of the Greek Bible (without doubt he drew here from AnPS and AnPG and not solely LV). That is why Wujek provided his translation with a marginal commentary, in which he gave the word in Greek, Aramaic, Syriac, Chaldean and Hebrew. In commenting on the verse, when it comes to Peter's Primacy, Wujek clearly focuses on the dispute with the Protestants. Furthermore, in his argument, he uses a work by Elia Levita, a Jewish grammarian. Wujek conveyed the word ecclesiam ( neither as zbór nor as cerkiew, but as kościót. Moreover, Wujek demonstrated the uniqueness of Simon's person, in whose name his exceptional mission and power have since been reflected. That is why he mentioned in a margin that the Gates of Hell shall not defeat both the Church and Peter himself on whom the Church 
is to be built like a house on the rock - again the polemics on the Primacy of Peter. It is noteworthy that in a commentary Stanisław Murzynowski and translators of the Budny's Bible give the Protestant interpretation of the text, emphasising the foundation of the Church upon Christ and indicating Peter's faith, which is symbolised here by the rock.

Verse 19:

1593 WNT: ${ }^{k}$ I tobie dam klucze królestwa niebieskiego. A cokolwiek zwiążesz na ziemi, będzie związano - i’ w niebiesiech, a cokolwiek rozwiążesz na ziemi będzie rozwiązano $\bullet$ i' w niebiesiech.

- 9 L. G. S.

- G.

${ }^{k}$ Mt. 18:18

Jn. 20:23

I tobie dam klucze.) Przez te klucze rozumie się nawyższą zwierzchność i przełożeństwo dane Piotrowi nad wszytkim Kościołem, to jest moc rozsądzania nauk, jeśli są prawdziwe abo fałszywe; i praw stanowienia i zgromadzenia synodów i pirwszy głos na nich i potwierdzenia ich; poświęcania i stanowienia biskupów i składania ich i moc szafowania dobry kościelnymi, tak duchownymi jak i świeckimi. Abowiem taka moc i zwierzchność Pismo Ś[więte] na wielu miejscach wyraża przez klucze, jako ono tedy opisuje złożenie jednego biskupa najwyższego, a obranie inszego tymi słowy: „A dam klucz Domu Dawidowego na ramie jego i zawrze, a żaden nie otworzy, otworzy, a żaden nie zawrze" [Isa. 22:22]. Także w objawieniu, jako przełożonemu miejskiemu i gospodarzowi domowemu, daniem kluczy zwierzchność nad miastem abo nad domem zlecają [Rev.: 1:18; 3:7]. A tak tymi słowy jako ś[w.] Grzegorz i ś[w.] Chryzostom piszą: „Poruczył Pan Piotrowi wszytek świat i uczynił go pasterzem i głową Kościoła wszytkiego" [Gre: epist. 32, Chry: homil: 55 in Matthaeum]. 
A cokolwiek zwiążesz.) W Piśmie Ś [więtym] ten zwięzuje, który rozkazuje i który karze. O rozkazaniach Pan ono mówi: „Wiążą brzemiona cięszkie i trudne ku noszeniu i kładą na ramiona ludzkie" [Mt. 23:4]. A o karaniu: "Cokolwiek zwiążecie na ziemi” [Mt. 18:18]. Ludzie lepak bywają obowiązani, tak na zachowanie rozkazania przełożonych kościelnych, jako i na podjęcie karania, jeśli ich nie chowali. A ten zaś rozwiązuje, który odpuszcza grzechy, który wyzwala od karania, który wolnymi czyni od ustaw, od ślubów, od przysiąg i od innych obowiązek podobnych. A tak gdy Pan Piotrowi mówi w obecz: Cokolwiek zwiążesz abo rozwiążesz, że daje mu moc zupełną rozkazowania, karania, zaklinania, wyzwalania, odpuszczania, rozgrzeszania i odpustów dawania, aby był i sędzią i przełożonym zgoła wszytkich, którzy są w Kościele.

LV: $\quad \quad$ Et tibi dabo claves regni caelorum. Et quodcumque ligaveris super terram, erit ligatum $\triangleright \&$ ' in caelis, \& quodcumque solveris super terram, erit solutum $\triangleright \&$ ' in caelis. Mt. 18:18

Jn. 20:23

et $21: 13$

- 9 MS.

Hier. G. S.

AnPS: $\quad$ Tibi dabo claves regni caelorum; \& quidquid ligaveris in terra, erit ligatum in caelis \& quod solveris in terra, erit solutum in caelis.

AnPV: $\quad$ Et tibi dabo claves regni caelorum. Et quodcunque ligaveris super terram, erit ligatum $\&$ in cealis; $\&$ quodcunque solveris super terram, erit solutum $\&$ in caelis.

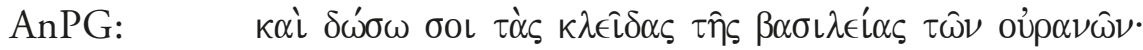

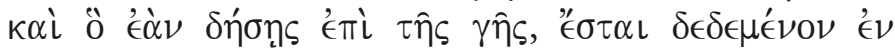

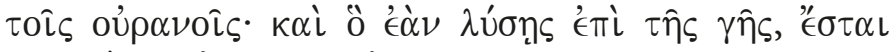

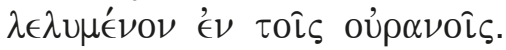

Mt. 18:18

Jn. 20:23 
The Biblical scholar form Wagrowiec follows the text of LV, translating twice $e t$, which is absent in the Greek version. The same signs (arrows) and notes as in LV appear in the Wujek's text (with the exception of the reference to Jn. 21:13).

Verse 20:

1593 WNT: Tedy przykazał uczniom swoim aby nikomu nie powiedali że on jest $・$ Jezusem' Chrystusem.

- 6 L. N. G. S.

LV: $\quad$ Tunc preacepit discipulis suis ut nemini dicerent quia ipse esset $\bullet$ Iesus' Christus.

- $6 \mathrm{MS}$.

G. q. s.

AnPS: $\quad$ Tunc praecepit discipulis suis, ut nemini dicerent ipsum esse Meschicho.

AnPV: $\quad$ Tunc praecepit discipulis suis ut nemini dicerent, quia ipse esset Iesus Christus.

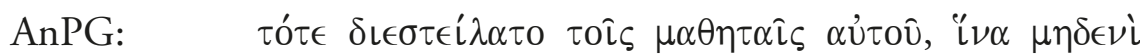

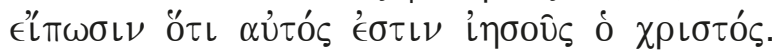

Again, Wujek borrows critical textual notes from LV. The translation is compatible with the word order of all the Latin texts, which, this time, do not use the $A C I$ syntax, but a word order determined by the conjunction quia.

The conducted study of the pericope Mt. 16:13-20, based on the original sixteenth-century editions of the Biblical texts, allowed drawing final conclusions on the commentary and translation methods used by Wujek. As the basis for the translation, he had chosen mainly LV. It applies not only to the text but also to the references to the parallel places and critical textual notes. Therefore, the comparative study of the texts showed that the notes were not by Wujek himself, but were drawn from LV. Wujek simply copied them and did not have to write the critique of a text himself. This finding was made possible because the same original sixteenth-century editions of the Bible were used in the analysis above as Jakub Wujek did. So it should be pointed out that working with random editions 
may lead to the misperception of a translation practice of the Jesuit from Wagrowiec. The translator did not always slavishly follow the Latin text. Sometimes he departed from the Latin syntax and was searching for a more correct word order in Polish. His translation - and especially the commentary - was of polemical nature, aimed at the Antitrinitarians (the issue of Christ's Divinity) and generally at the Reformation movements (the problem of Peter's Primacy). When it comes to the influence of LV on the whole Gospel of Matthew, there is almost a $100 \%$ dependency between LV and the $1593 \mathrm{WNT}^{28}$

\section{Abbreviations}

1593 WNT - 1593 Wujek's translation of New Testament ACI - accusativus cum infinitivo

AnP - Antwerp Polyglot

AnPG- Antwerp Polyglot (Greek text)

AnPS - Antwerp Polyglot (Syriac text)

AnPV - Antwerp Polyglot (Latin text)

August: In psa: cont. par. don. - Augustine, in psalmus Contra Partem Donati Basi: hom: de poenit. - Basil, homily De poenitentia

Chry: homil: 55 - John Chrysostom, a homily 55

G. - (texts) Greek

G. q. s. - Greek (texts), from the Latin quantum satis - as much as is needed Gre: epist. 32. - Gregory, epistle 32

Hier. G. S. - Jerome, Greek, Syriac (texts)

Hiero - Jerome

Hom., Homil. - Homily

Isa. - Book of Isaiah

Jn. - Gospel of John

L. G. S. - Latin, Greek, Syriac (texts)

L. K. G. S. - Latin (Louvain Vulgate), Royal (Antwerp Polyglot), Greek, Syriac (texts)

L. N. G. S. - Latin (L.N.), Greek, Syriac (texts)

Lk. - Gospel of Luke

LV - Louvain Vulgate

Mk. - Gospel of Mark

MS. - manuscripts

${ }^{28}$ Counting the references will show that Wujek copied 579 biblical sigla from LV, i.e. over $90 \%$ of all the marginal notes. 
MS. R. G. S. at Hier. - Royal, Greek, Syriac manuscripts in Jerome

Mt. - Gospel of Matthew

NT - New Testament

OT - Old Testament

Rev. - Book of Revelation (Apocalypse of John)

inner - inner margin

outer - outer margin

\section{Bibliography}

Biblia Sacra Hebraice, Chaldaice, Graece et Latine. Philippi II Reg. Cathol. Pietate Et Studio Ad Sacrosanctae Ecclesiae Usum, vol. 1-8 (Antverpiae, 1569-1572)

Biblia sacra: Quid in hac ediotione a Theologis Louaniensibus praesitum sit, paolo post indicator (Antverpiae: K. Plantinus, 1574)

Biblia to iest Księgi Starego y Nowego Testamentu wedtug Eacińskiego przektadu starego, w kośćiele powszechnym przyiętego, na Polski ięzyk z nowu z pilnościa przetożone. $Z$ doktadaniem textu Żydowskiego y Greckiego, y z wyktadem Katholickim, trudnieyszych mieysc, do obrony Wiary świętej i powszechney przeciw kacerztwom tych czasów należących. Przez D. Jakuba Wuyka z Wagrowca Theologa Societatis Iesu. W Krakowie, Roku Pańskiego M.D.XCIX, ed. I. Kwilecka, H. Rothe (Padeborn, München and Wien, 2010; Biblia Slavica. Polnische Bibeln, V/1-2)

Bieńkowska D., "Jak Jakub Wujek Pismo Święte na język polski przekładał (O warsztacie tłumacza i technice przez niego stosowanej)," Bobolanum 9 (1998)

Bieńkowska D., "Rola glos marginalnych w przekładzie Biblii J. Wujka," Acta Universitatis Lodziensis. Folia Linguistica 23 (1990)

Bieńkowska D., Styl jezykowy przektadu Nowego Testamentu Jakuba Wujka (na materiale czterech Ewangelii) (Łódź, 1992)

Czerniatowicz J., Niektóre problemy naukowe grecystyki w pracach biblistów polskich XVI i XVII wieku. Teksty greckie a polskie przektady (Wrocław, 1969; Monografie w Dziejów Nauki i Techniki, vol. 53)

Kossowska M., Biblia w jezyku polskim, vol. 1 (Poznań, 1968)

Kuźmina D., Jakub Wujek (1541-1597). Pisarz, thumacz i misjonarz (Warszawa, 2004)

Langkammer H., "Przekład Biblii Wujka na tle zmagań i potrzeb religijno-teologicznych ówczesnego Kościoła w Polsce," Bobolanum 9 (1998)

Moszyński L. "Stworzenie świata (Gn 1,1-31) w przekładzie Wujka z Wulgaty (1599) i Budnego z hebrajskiego (1572)," in: Jan Jakub Wujek. Ttumacz Biblii na jezyk polski. W czterechsetna rocznice wydania Nowego 
Testamentu 1593-1993. Ksiega referatów wygtoszonych na konferencji 26 kwietnia 1993 (Łódź, 1994)

Nowy Testament Pana naszego IESVSA CHRISTVSA. Z nowu z Laćińskiego y z Gręckiego na Polskie wiernie a szczyrze przetożony: y Argumentami abo Summariuszami każdych Kśiag / y Rozdźiatow / y Annotacyami po brzegach obiaśniony. Przydane sa Nauki y Przestrogi mato nie za każdym Rozdźiatem: Porownanie Ewangelistow SS. Dźieie y drogi rozmaite Piotra y Pawta S. y Regestr rzeczy gtownieyszych na końcu. Przez D. IAKVBA WVYKA, Theologa Societatis IESV. Z dozwoleniem Starszych. Pod rozsadek Kościota S. Powszechnego Rzymskiego wszytko niech podlęże (Kraków, 1593)

Pietkiewicz R., W poszukiwaniu "szczyrego" Stowa Bożego. Recepcja zachodnioeuropejskiej hebraistyki $w$ studiach chrześcijanskich $w$ Rzeczypospolitej dobry renesansu (Wrocław, 2011; Rozprawy naukowe PWT, vol. 86)

Sawicki S., "Biblia Wujka w kulturze polskiej," Studia Gnieźnieńskie 1 (1975) Siatkowska E., "Samodzielność przekładu Nowego Testamentu przez Jakuba Wujka, Jana Blahoslava i Michała Frencla," in: Biblia a kultura Europy. 2000 lat chrześcijaństwa, vol. 1, ed. M. Kamińska, E. Małek (Łódź, 1992) Sobczykowa J., Myśl o jezyku w komentarzu biblijnym ks. Jakuba Wujka (Katowice, 2001)

Voste G., "La volgata al Concilio di Trento," Biblica 27 (1946)

\begin{abstract}
The article is devoted to the influence of the Louvain edition of the Vulgate on the workshop of Jakub Wujek, one of the most famous sixteenth-century translators of the Bible. This relationship is shown based on the example of the pericope concerning the promise of the primacy of St. Peter from Matthew 16:13-20. Until now, studies of the method of the Jesuit from Wagrowiec have availed themselves at random of various editions of the Vulgate (different from those used by the translator, including even modern translations), leading to erroneous conclusions about his workshop. The article comprises the exact editions on which Wujek based his work. This method enabled the discovery that the marginal notes added to the text by the translator were not compiled by him, but transcribed from the Louvain edition of the Vulgate.

Ke yw o rds: Jakub Wujek, Bible translations, Louvain edition of the Vulgate, Protestant Reformation, primacy of St. Peter, Gospel according to Matthew
\end{abstract}


Paulina Nicko-Stepień, PhD student at the Institute of the Classical, Mediterranean and Oriental Studies of the Wroctaw University and at the Pontifical Faculty of Theology in Wrocław. She conducts research on Biblical studies, especially the Archaeology and Biblical Philology.

E-mail: paulina.nicko-stepien@uwr.edu.pl

Trans. by Agnieszka Pospiszil

First published as: "Wulgata Lowańska a Nowy Testament w przekładzie ks. Jakuba Wujka z roku 1593. Studium Mt 16, 13-20," Odrodzenie i Reformacja $w$ Polsce 59 (2015), pp. 47-66

The publication of this English translation has received additional funding from the Ministry of Science and Higher Education of the Republic of Poland 